\title{
Level of Applying the Transformational Leadership by Principals of Secondary Schools and its Impact on Teachers' Empowerment: an Empirical Study on Public Secondary Schools at Muaqqar \& Al-Jeeza Educational Region in Jordan
}

\author{
Dr. Saud Al-Khreisha ${ }^{1}$ \\ ${ }^{1}$ Faculty of Educational Science, The World Islamic Science \& Education University, Amman - Jordan \\ Correspondence: Dr. Saud Al-Khreisha, Faculty of Educational Science, The World Islamic Science \& \\ Education University, Amman - Jordan. E-mail: Ibrahim_hasanat@hotmail.com
}

Received: July 20, 2019

Accepted: August 21, 2019

Online Published: August 28, 2019

doi:10.5539/mas.v13n9p87

URL: https://doi.org/10.5539/mas.v13n9p87

\begin{abstract}
The study aimed at investigating the level of applying transformational leadership pattern by Secondary School principals at Muaqqar \& Al-Jeeza educational region and the effect of this on empowering teachers and enabling them to perform their educational message. A questionnaire was designed and distributed on a simple random sample consisted of (340) of the Secondary school principals or teachers at Al-Muaqqar \& Al-Jeeza educational regions. A number of 315 questionnaires have been returned back at a response rate of $92 \% .64$. Statistical analysis was carried out using the program of statistical package for social sciences SPSS. After conducting analysis and testing of hypothesis, the study an accepted level of applying transformational leadership among high school principals in the studied region. The study also revealed a statistically significant effect of this leadership pattern on the empowerment of teachers at these schools.
\end{abstract}

Keywords: transformational leadership, empowerment, charismatic, motive motivation, individual mindfulness, intellectual excitement

\section{Introduction}

The gigantic changes and the accelerating incidents of the environment in which we live had imposed a vigorous state of ambiguity and uncertainty, put individuals and organizations in front of difficult challenges obliged them to make happen a change in their practices, behavior and the way of their performance of their works if they wanted to response to these variables and to adapt with them, in front of these schools that are considered factories of the coming generations and in which the future of the nation (Ommah) is specified. Schools to be able to perform this great message, they have to change the way of their performance to escort the technological, cultural, and social variables that happen in the environment and with what makes it able to build the ambitious learned man, the enthusiastic and innovator with the open minded and open to the other, able to deal with the modern technological means and with what makes the nation able to compete other nations in different domains. For the sake of these schools need proficient principals lead them towards this goal and empower their teachers to perform the educational message that promotes the nation to a position it deserves among nations.

From the most important traits of the successful administrative leader is sincerity, an accomplishment of work properly, and laying the appropriate man in the appropriate place, putting the public interest first above personal consideration, to be enthusiastic perseverant and inspiring others, bearing values and principles deserves for them, to be believer of his principles and concerned about his subordinates and participating them in managing the work, tersely he should be a transformational leader in the deepest and the simplest definition of it that he is that person who takes his followers to a place they did not imagine that they are able to reach.

Depending on what preceded, this study had come to make sure of the extent of practice of the Secondary Schools principles at Al-Muaqqar and Al-Jeeza region of the transformational leadership pattern at its effect in empowering the teachers of performing their educational message.

\section{Problem of Study}

Seeking the development of the educational process in Jordan, and aims at escorting changes imposed by the 
process of openness resulting from globalization, the responsible parties in Jordan had worked on doing changes in plans, programs and educational policies for the sake of improving the type of educational outputs, either on the students' level, teachers or educational institutions in Jordan, one of these important changes is the way of dealing with the students at school and changing the form of relationship' among the principal, the teacher and the student, for the relationship formerly had been performed on that the principal is the commander and prohibitor and the teachers are purely executions of the principals decisions and instructions and reports are in the hand of the principal and he issues the evaluation he sees suitable about the teacher to the responsible parties, and the same thing in the relationship of the teacher with the student; the teacher is the person in whose hand the destiny of the student in success, failure and deprivation, the principal and the teacher punish the student sometimes by hitting believing that this is in his interest on the rule "we studied" and succeeded and do the same thing with our students desiring their future, but that in reality was one of the delay causes and retreat in the position of Jordan and states that follow the same technique on the scale of the worldly evaluation of educational process at schools, and this is what is called "The Technique of Mutual Leadership". Therefore the Ministry of Education had sought since decades to change this approach it organized intensified training courses for principals of schools, teachers and attracted experts and specialists for that, and introduced information technology, modern social media means in managing school administration and managing the educational process. It also prevented beating students at schools and asked to replace that by performing new relations in which the principal and the teacher are an example for the student and friends of them and instructors who lead the student towards his future, and the relationship is to be performed on trust, love, and feeling with responsibility towards the student. Teachers plant values of the good, love, and wish in distinction, innovation and respect of the other openness to him and work altogether as one team.. this is called the technique of "Transformational Leadership". For this the study had come to measure the extent of principals application of the technique for "Transformational Leadership" in their management of schools from the teachers' point of view and the effect of that on empowering teachers at school of performing their educational message as the modern Jordanian state wanted, for that this study will attempt to answer the following questions:

1. What is the level of principals of Public Secondary Schools application at both regions of Muaqqar and Al-Jeeza of the Transformational Leadership pattern?

And emerges from this question the following subsidiary questions:

冈 What is the level of principals of Public Secondary Schools application at both regions of Muaqqar and Al-Jeeza of the concept of the idea influence in the Transformational Leadership?

What is the level of principals of Public Secondary Schools application at both regions of Muaqqar and Al-Jeeza of the concept of inspirational motivation in the Transformational Leadership?

What is the level of principals of Public Secondary Schools application at both regions of Muaqqar and Al-Jeeza of the concept of intellectual excitement in the Transformational Leadership?

What is the level of principals of Public Secondary Schools at both regions of Muaqqar and Al-Jeeza of the concept of individual considerations in the Transformational Leadership?

2. What is the level of teachers empowerment at the Public Secondary Schools at both regions of Muaqqar and Al-Jeeza?

3. What is the effect of applying the pattern of the Transformational Leadership empowering teachers at the Public Secondary Schools at both regions of Muaqqar and Al-Jeeza?

\subsection{Significance of Study}

The significance of study springs from numerous sides, the first of them is the significance of the community which the study tackled, it is school that forms side by side with the family the most important two social entities in which the future of the nation is drawn. Schools is the factory in which characteristics and specifications of the coming generation are made. The secondary school in particular forms the separating limit between the generation's adolescence, the maturity and its point of start towards the future.. in it mile-stones of a student's personality are drawn, whom we seek to make him concern about science and knowledge and use the modernist technological means, and to be enthusiastic and innovator bearing inside himself the values of the nation and its principles and to be treated with the soul of cooperation, participation, openness and acceptance of the other. The second significance of the study comes from the subject it tackled.. it is the Transformational Leadership that we hope to prevail between our principals and teachers in their dealing with each other and their dealing with the students to be open persons, innovators, and enthusiastic to renaissance of the nation, also this study considered 
applying may be with significance through the field results that communicate with it and be allowed in hands of the concerned people in decision- making in developing the educational process.

\subsection{Objectives of Study}

The study aimed at the following:

1. Measuring the level of applying by principals of Public Secondary Schools at both regions of Muaqqar and Al-Jeeza to the pattern of Transformational Leadership.

And had emerged from this main objective, the following subsidiary objectives:

冈 Measuring the level applying by principals of Public Secondary Schools at both regions of Muaqqar and Al-Jeeza to the concept of ideal effect in the Transformational leadership.

冈 Measuring the level applying by principals of Public Secondary Schools at both regions Muaqqar and Al-Jeeza to the concept of inspirational motivation in the Transformational leadership.

冈 Measuring the level applying by principals of Public Secondary Schools at both regions of Muaqqar and Al-Jeeza to the concept of intellectual excitement in the Transformational leadership.

$\otimes \quad$ Measuring the level applying by principals of Public Secondary Schools at both regions of Muaqqar and Al-Jeeza to the concept of the individual consideration in the Transformational leadership.

2. Measuring the level of empowering teachers at the Pubic Secondary Schools at both regions of Muaqqar and Al-Jeeza.

3. Making sure of the extent affecting applying the pattern of the Transformational Leadership on empowering teachers at the Public Secondary Schools at both regions of Muaqqar and Al-Jeeza.

\subsection{Hypothesis of Study}

Ho1:first main hypothesis: there is no statistical guide at $(\mathrm{H} \geq 3.67, \alpha \leq 0.05)$ on Principals of Public Secondary Schools practice at both regions of Muaqqar and Al-Jeeza to the pattern of Transformational Leadership.

It had emerged from this main hypothesis the following subsidiary hypotheses:

Ho11: the first subsidiary hypothesis: there is no statistical guide at $(\mathrm{H} \geq 3.67, \alpha \leq 0.05)$ on Principals of Public Secondary Schools practice at both regions of Muqqar and Al-Jeeza to the concept of the ideal, effect.

Ho12: the second subsidiary hypothesis: there is no statistical guide at $(H \geq 3.67, \alpha \leq 0.05)$ on Principals of Public Secondary Schools practice at both regions of Muqqar and Al-Jeeza to the concept of inspirational motivation.

Ho13: the third subsidiary hypothesis: there is no statistical guide at $(\mathrm{H} \geq 3.67, \alpha \leq 0.05)$ on Principals of Public Secondary Schools practice at both regions of Muqqar and Al-Jeeza to the concept of the intellectual excitement.

Ho14: the fourth subsidiary hypothesis: there is no statistical guide at $(H \geq 3.67, \alpha \leq 0.05)$ on Principals of Public Secondary Schools at both regions of Muqqar and Al-Jeeza to the concept of the individual considerations.

Ho2: the second main hypothesis: there is no effect with statistical significance at $\alpha \leq 0.05$ ) to Principals of Public Secondary Schools application at both regions of Muaqqar and Al-Jeeza to the pattern of Transformational Leadership on empowering employees at those schools.

\subsection{Model of Study and Its Variables}

Form (1) clears the variables of study and nature of relationship that will be tested among these variables, they are as follows:

The independent variable:

The transformational leadership, it is a pattern of leadership, in which the leader forms a source of inspiration to his subordinates with what he shows of principles and values in them the public interest is being upper-handed over the individual interest and leader is motivating to his subordinates, irritating the enthusiasm and innovation and a model in insistence on attaining far destinations of the organization (Tomey, 2009).

And inspite of the multitude of elements consisting this pattern, the following elements had been chosen, they are called "the independent subsidiary variables":

- The ideal effect: it is the leader's showing feelings of respect of his subordinates and exciting the feelings of enthusiasm at them and wish in challenge and belief in ability to attain the far destination and considering the leader like them in that (Woods, 2003).

- The intellectual excitement: it is ability of the leader to push his subordinates to confront problems by 
new methods and find innovated solutions to overstep difficulties and deal with problems. (Bass, 1994).

- The individual consideration: it is ability of the leader to perceive the individual differences among his subordinates and deal with everyone of them with what observes these differences and work to reinforce points of power and treat points of weakness in the personality of the subordinate (Barbuto, 2006).

Form No. (1) Depended from Amira Ghannam's Study

\begin{tabular}{|l|}
\hline Independent Variable \\
\hline Transformational Leadership \\
\hline Ideal Effect \\
\hline Inspirational Motivation \\
\hline Intellectual Excitement \\
\hline Individual Consideration \\
\hline
\end{tabular}

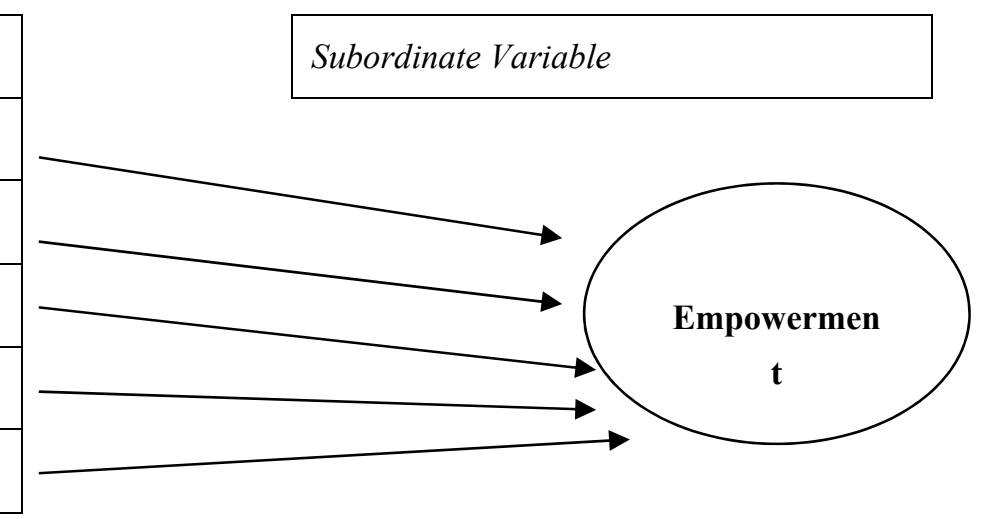

\section{Source: prepared by the researcher}

\section{Literature Revision}

In clarifying the difference between principals and the leaders, it is clarified that principals reinforce stability, reliability and keeping the prevailing system and problem solving within the organizational frames according to instructions of the acting work system, meanwhile the leaders reinforce the far vision, innovation, changed and problem solving by innovated methods. (Khaireddin, 2015) adds that the principal is that person to whom the task of supervising a unit or a work group (administration, department, section,.. and else) and practices functions of administration in planning, organizing, directing (leadership) and control to achieve objectives of the organization, and he acquires his authorities in the organization from the formal organization, who specifies the tasks, responsibilities and competences of decision-making, communication systems, and means of control in the organization. But the leader had been born in the informal organization, when employees whose interests had not been achieved in the organization refused to entrust persons possess the ability to defend their interests, and so affected by the ability of these persons on persuasion, influencing and motivating employees to defend their interests and achieve their objectives and established for themselves values and standards..defended them, these persons had been called 'leaders', with the increase of complication level and dynamics in the environment of works, their organizations, vigour of competition sharpness and increase of work groups pressure, the classical methods by which principals manages their organizations and perform the classical functions of the principal, they had never been suitable and nor able to confront challenges that confront organizations and principals in the contemporary works environment, so the principals had to enjoy leading attributes through which they can lead individuals at their organizations by new means in the organization (work-teams), motivating them and exciting their motives to achieve objectives of the organization by a proficient and effective way filled with hastiness and enthusiasm from here started the concept of administrative leadership.

And inspite of multitude of theories in explaining the leader and the prevailing leading patterns, but they are all enlisted under two basic techniques, they are the traditional classic technique, in which the leader is nearer to the personality of principals more than leaders, where the leader is considered the inspired, he is the one who thinks and others are tools to carry out his thoughts, they have to show loyalty and following instructions and respect laws, he who did that is rewarded and who neglects should be punished. But the other pattern is the modern pattern or the democratic one, in which leaders are actually inspired to their followers, but not through subjugation but through values, joint- principles, mutual respect, and through overcoming the public on the particular, and granting freedom to followers and motivate them to search for innovated methods to process problems. From this point I prefer classifying leaders.. he is the one who shortened the different classifications in two patters: they are pattern of Transformational Leadership and pattern of Transformational Leadership. The talk had started about this pattern, specifically the Transformational Leadership in the eighties of the past century when (Bass, 1985) did prepare a revised deepened study was prepared for works of both (Hause, 1976) and (Burns , 1978), then researchers followed consecutively till now to tackle both leading patterns, studies indicate to that Transformational Leadership lean on the utility. Theory, that is the leader exchange a certain value like loyalty and obedience in return for stability with his subordinates, or offers the good performance and attains the 
reward and if was not committed to instructions and did not accomplish what is hoped of him he is exposed to punishment. For this it is said that one of the most important traits of the Transformational Leadership is the principle of reward and punishment. But the Transformational Leadership it leans on the Contingency Theory and on the school of organizational Behavior that depends on the leader's behavior values and the ethical principles that he leads and males the public triumph over the particular and his behavior is truly inspirational and followers desire to follow him and do motivate them to succeed and attain the goal by new innovated methods. Inspite of some partial differences in specifying the elements of Transformational Leadership, but most researchers like (Avolio, 1994), (Bass, 1994), (Barbuto\&Burbach, 2006), (Tomey, 2009). They assembled on the most important elements in the Transformational Leadership are:

\section{囚 Ideal influence \\ 囚 Inspirational motivation \\ 冈 Intellectual excitement \\ 囚 Individual consideration}

Nabil's study 2015) had tackled the Transformational Leadership as it is the process in which the individual participates with others, and consists ties promote the level of motivation and ethics at both of the leader and the subordinate. It concerns as a one of the modernist and comprehensive leading approaches in the process of how certain leaders are able to inspire subordinates to accomplish great tasks, the leader attempts in it to change the joint organizational values of his company to reflect a more just and humanitarian standard. Thereupon the principal and the subordinates attain a group of ethical values more powerful and higher than the previous values. Also considered that the transformational leaders are the leaders who inspire their subordinates and sublime over their self-interests for the interest of the organization objectives, and they are able to essential and great influence on their subordinates and concern about the issues and matters related with the need to develop the subordinates and change their perception of issues and problems through looking into matters and problems a new look, and they are able to inspire and excite individuals and motivates them to exert a duplicated effort to achieve objectives of the organization and let them reach a performance surpasses expectations.

Ismael's study (2015) tackled the concept of Transformational Leadership and paraphrase of its dimensions leaning on Avolio's classification (1996) of the Transformational Leadership dimensions as it is: Firstly: attraction (ideal influence), where it describes the leader's behavior that acquires admiration, respect and subordinates' esteem. That requires participation in dangers by the leader and offer the subordinates' needs before the leader's personal needs and performs behavior with ethical nature. Secondly: inspirational motivation, this dimension concentrates on forms of behavior by the leader that excites challenge love in subordinates, those behavior forms work to clarify expectations of subordinates, describe the commitment style of organizational objectives, and exciting the soul of team work through enthusiasm and idealism. Thirdly: the intellectual excitement, in it the Transformational Leadership works on searching for the new ideas and encourages solving problems in an innovative way by the subordinates. Fourthly: individual consideration; this attribute appears through the leader's style, who kindly listens and entrusts a special concern for subordinates' needs, also their holidays through adopting estimation and commendation strategies.

Also Al-Kharabsha and Al-Maani's study (2015) entitled "Effect of Applying the Transformational Leadership on the Administrative Innovation in Balqa Applied University" aimed at defining the concept of Transformational Leadership and Characteristics of the Transformational Leadership and the most important applying- obstruction of this pattern in the administrative organizations and educational foundations. It also aimed at measuring the level of applying the Transformational Leadership in Balqa Applied University from the employees' point of view and be aware of the effect of applying the Transformational Leadership on the administrative innovation.

The study had deduced that the university applies the Transformational Leadership at a medium degree from the employees' perspective, and there is a high feeling with administrative innovation. The study also showed non-existence of differences with statistical significance in the imaginations of the researches towards the Transformational Leadership refers to their demographic characteristics except for the social type.

Al-Somali and Mutwali study (2018) discussed in the effect of the Transformational Leadership on empowering and innovating the acting administrative employees working at higher education foundations in the Saudi Arab Kingdom, and the study had been carried out on the administrative employees at King Abdel Aziz University. The study had deduced existence of a positive and strong relationship between the Transformational Leadership and empowering the employees, positive and strong too to the Transformational Leadership with the 
administrative innovation of the employees. The study also deduced that the university practices the Transformational Leadership at a high rate.

But Al-Shammari's study (2017) had tackled using introduction of the Transformational Leadership in developing management of intermediate schools in the State of Kuwait, and deduced that administrations of the mentioned schools practice the Transformational Leadership at a high rate, also all elements of the Transformational Leadership, tackled from the researcher's point of view, they are the attraction, motivation, mental excitement, and the individual considerations, they all had been high.

Jacob's study (2017) had tackled the topic of teachers' perception at secondary schools for the level of empowerment granted to them by their schools principals. The study tackled two sides the first of them both: the supporting frames of empowerment, they bare the principals training, the leading pattern of principals, the leading pattern of teachers and school culture. The second of them both is empowerment; it is the meaning, competence, self- determination and impact. The study deduced that school culture has a greater impact than other frames in the process of empowerment, and the most perceived elements of empowerment at teachers are both meaning and competence.

\section{Methodology of study}

Introduction: this section tackles the method, procedures, and employed styles in deducing the results of study and securing its objectives containing specification of the community of study and choosing its sample and employed tools in collecting data and the employed statistical methods in choosing the validity and reliability of the tool of data collecting, their dependence and their competence to statistical analysis and in describing the demographic characteristics of the sample of study and describing variables of study, in addition to clarifying the analytical statistical styles, employed in answering questions of study and testing its hypothesis.

This field study had depended on both styles, the descriptive and the analytical, where the descriptive statistics had been employed in describing the demographic characteristics for the individuals of study samples, they are the public school teachers at both directorates of Muaqqar and Al-Jeeza by counting repetitions and percentages of them and also counting the accumulated repetitions, and employing the descriptive style too in describing the independent and subordinate variables of study, that is by counting the hoped central propensity of study (arithmetic mean variation, standard deviation, the extent) for the independent main variable: the transformational leadership of the researched school principals, from the teachers' point of view, and the subordinate subsidiary variables: ideal excitement, inspiration motivation, intellectual excitement, and the individual considerations. Also counting the same statistical measures for the main variable following teachers' empowerment. Also the analytical statistics had been employed in the validity and reliability of study tool and it testing reliability of data and the level of their natural distribution. And also the extent of their validity to the statistical test and answering the questions of study and testing its hypothesis. These statistical analysis had been done at the significance $(\alpha \leq 0.05)$ that is a tan internal of confidence $=0.95$ and at an arithmetic mean $(\mathrm{H} \geq .67)$ also all analysis were done by employing the Statistical Pacage of Social Sciences SPSS.

\subsection{Community and Sample of Study}

\subsubsection{Community of study}

The community of study consists of all teachers males and females, who work at the Public Secondary Schools at both directorates of Muaqqar and Al-Jeeza in Sahab Governorate in the Hashemite Kingdom of Jordan, and according to the available data at the educational zone the number of teachers is 2564 males and females as cleared in table 1.

Table 1. A table pin-points the community of study: preparation of teachers at both directorates of Muaqqar and Al-Jeeza

\begin{tabular}{ccc}
\hline Data & Muaqqar Directorate & Al-Jeeza Directorate \\
\hline No. of male schools & 27 & 42 \\
No. of female schools & 33 & 58 \\
Table of schools numbers & 60 & 100 \\
Teachers' number & 409 & 571 \\
Female teachers No. & 596 & 988 \\
Total of teachers' number & 1005 & 1559 \\
\hline
\end{tabular}

Source: Ministry of Education available data at Directorate of Education in Sahab Zone. 


\subsection{Sample of Study}

A class random sample had been chosen a size of 340 male and female teachers. Its size had been specified leaning on a table specifying the size of the sample from a certain community (Uma-Sekaran, 2006, 294), and the sample had been classily distributed as illustrated in table 2 .

Table 2.

\begin{tabular}{cccc}
\hline Data & Community & Rote from the community & Sample \\
\hline $\begin{array}{c}\text { Female Teachers at Al-Muaqqar } \\
\text { Directorate }\end{array}$ & 596 & 0.23 & 79 \\
$\begin{array}{c}\text { Male Teachers at Al-Muaqqar } \\
\text { Directorate }\end{array}$ & 409 & 0.16 & 54 \\
$\quad \begin{array}{c}\text { Female Teachers at Al-Jeeza } \\
\text { Directorate }\end{array}$ & 988 & 0.39 & 132 \\
$\begin{array}{c}\text { Male Teachers at Al-Jeeza Directorate } \\
\text { Gross Total of Teachers No. }\end{array}$ & 571 & 0.22 & 75 \\
& 2564 & 1.0 & 340
\end{tabular}

Prepared by the researcher leaning on the way to specify the class sample from a community of well-known categories.

After doing the descriptive analysis to the sample of study, results showed as illustrated in table No. (3) that $\% 61.9$ are of female teachers and that $\% 38.1$ from males. This is a positive indicator of the woman's role in the process of human development. Also results showed that $\% 88.3$ of teachers are bearers of B.A. (Bachelor of Arts) and the \%54 of bearers of M.A (Master Degree) and \%1.6 of bearers of Doctorate. This is an indicator to height of the academic level of teachers at that zone, in addition to what preceded, the results had shown that $\% 50.2$ of teachers are of ages below (40) forty years of youths. This is also another positive indicator.

Table 3. The demographic characteristics of the sample of study

\begin{tabular}{cccc}
\hline Demographic variable & Class & Repetition & Percentage \\
\hline The social type & Male & 120 & $\% 38.1$ \\
& Female & 195 & $\% 61.9$ \\
& Total & 315 & $\% 100$ \\
Scientific & Below B. A. & 15 & $\% 4.8$ \\
obtainment & B. A. & 278 & $\% 88.3$ \\
& M. A. & 17 & $\% 5.4$ \\
& Doctorate & 5 & $\% 1.6$ \\
& Total & & $\% 100$ \\
Age & Less than 30 years & 92 & $\% 50.2$ \\
& $31-40$ years & 158 & $\% 17.8$ \\
& $41-50$ years & 56 & $\% 2.9$ \\
& $51-60$ years & 9 & $\% 100$
\end{tabular}

4.3 Tool of Study

The study depended in collecting data employed in their preparation on two basic sources, they are: the secondary sources, that included books, articles, scientific researches, previous studies published in the scientific referred periodicals, bulletins, and scientific conferences, in addition to the electronic libraries and formal and referred data basis existing on the internal. And the initial sources used on purpose of collecting data from the sample of study for statistical analysis purposes aiming at answering the questions of study and testing the hypotheses.

For collecting the initial data a questionnaire consisted of a covering letter and parts. The covering letter came to urge individuals to answer questions of study and these answers have to be at the highest range of accuracy and objectivity and thanked them for doing that. The first part had related with collecting data related with the 
demographic characteristics and personal information of the study sample individuals, such as the social type, age and studying obtainment. But the second part had included the questions employed to collect data related with the main independent variable (transformational leadership) and the subsidiary variables belonging to it (ideal influence, inspiration motivation, intellectual excitement, individual considerations). Also data related with the subordinate variable (employees empowerment). (340) questionnaires had been distributed on teachers at the indicated community of study, and (335) answered questionnaires had been restored, but after doing the verification, twenty questionnaires violating the conditions and non-valid for statistical analysis had been excluded, so the number of questionnaires subordinate to the statistical analysis became (315) questionnaires at the rate of restoring the valid questionnaires equal $\% 92.64$.

\subsection{Tool of Study Test}

On purpose of making sure of the validity and reliability of study and the safety of data, their dependency and validity to the statistical analysis, the following tests had been done:

1. (Superficial validity of the tool): to make sure of the superficial validity of the study tool and suitability of its questions to collect data related with variables, the subject of study, and to make sure of the linguistic safety, simplicity clarity and correctness of questions the tool of study had been shown on a group of specialists and academicians (Appendix -1) and receiving their notes and instructions, and most of those notes had been taken into consideration, and this action is considered a condition of availability of the superficial validity of the tool (Umasekran, 2010, P.3).

2. (Internal consistency) and (reliability): to make sure of the consistency of study tool questions and reliability of data to measure the variables, the Cronbach- Alpha Test had been done. As the multitude research references indicated of them (Umasekran, 2010, P. 307) that considered the farthest value for the coefficient is right one and the tool and data enjoy with reliability and be valid for the scientific research and the statistical analysis if overstepped the value of Cronbach Alpha coefficient (0.6). as results of analysis appear in table No. 4..the test result for the independent variables and also results of analysis of the subordinate variable, all of them are higher than (0.6) and reached the main independent to $(0.952) \ldots$ they are high reliable, reliability of any of the independent main subsidiary all variables did not come less than $(0.0 .837)$ they are for the ideal influence, though they remain high and acceptable for the scientific research and the statistical analysis.

Table 4. (Cronbach- Alpha) Reliability test for study variables

\begin{tabular}{ccccc}
\hline Variable Type & Variable Description & No. of Questions & From-To & Cronbach Alpha \\
\hline Independent & Ideal Influence & 5 & $91-95$ & 0.837 \\
Variables & Inspiration Motivation & 5 & $96-910$ & 0.885 \\
& Intellectual Excitement & 5 & $911-915$ & 0.890 \\
& Individual Considerations & 5 & $916-920$ & 0.902 \\
& Transformational & 20 & $91-920$ & 0.952 \\
Leadership & & & \\
Subordinate & Employees Empowerment & 15 & $921-935$ & 0.949 \\
\hline
\end{tabular}

3. Normal Distribution of Date: to make sure of the extent of data subduing to normal distribution Kolmogorov Smirnov Test had been done. Results had shown as appear in table (5) that all data subdue to normal distribution, where the value of $(\alpha)$ should be less or equals $(0.05)$ as this test conditions and as appears from results, all of them locates under the level of hoped significance and this means that they subdue to the normal distribution. 
Table 5. Kolmogorov Smirnov Test for normal distribution of data

\begin{tabular}{cccc}
\hline Variable Type & Variable Description & $\boldsymbol{K}-\boldsymbol{S}$ & Sig. \\
\hline Independent Variables & Ideal Influence & 3.023 & 0.000 \\
& Inspiration Motivation & 2.839 & 0.000 \\
& Intellectual Excitement & 2.373 & 0.000 \\
& Individual Considerations & 2.693 & 0.000 \\
& Transformational Leadership & 2.485 & 0.000 \\
Subordinate Variable & Employees Empowerment & 2.178 & 0.000 \\
\hline
\end{tabular}

As a summary, results of study tool test showed that the tool of study was valid to what it had been designed and that it enjoyed validity and consistency, also data that had been collected by this tool was valid for purposes of doing the statistical analysis on it, where data enjoyed (reliability), correlation and was normally distributed.

\subsection{Test of Hypothesis}

4.5.1 Test of the first main hypothesis, and the subsidiary hypothesis belonging to it (Ho11, Ho12, Ho13, Ho14).

This hypothesis is concerned with testing the level of principals of Public Secondary Schools applying the pattern of Transformational Leadership and the subsidiary elements consistency this pattern of Leadership at both regions of Muaqqar and Al-Jeeza, they are: ideal influence, inspirational motivation, intellectual, excitement and the individual considerations. To achieve that, mean differences test had been employed..it is called "Two-tailed t-test" at an arithmetic mean $(H \geq 3.67)$ and at the significance level $(\alpha \leq 0.05)$. Results of the test by employing the program of statistical analysis SPSS as shown in table 6 .

Table 6. Results of T-test for the first main hypothesis test and the subsidiary hypothesis belonging to it and the second hypothesis

\begin{tabular}{|c|c|c|c|c|c|}
\hline \multirow[t]{2}{*}{ Variable } & \multirow{2}{*}{$\frac{\text { Test level }}{\text { t. value }}$} & \multicolumn{4}{|c|}{ Arithmetic Mean $=3.67$ test level at arithmetic mean } \\
\hline & & $\begin{array}{c}\text { Freedom } \\
\text { degree }\end{array}$ & $\begin{array}{c}\text { Significance } \\
\text { level }\end{array}$ & $\begin{array}{c}\text { Confidence } \\
\text { lower }\end{array}$ & $\begin{array}{c}\text { Period }=\% 95 \\
\text { higher }\end{array}$ \\
\hline Ideal Influence & 21.304 & 314 & 0.000 & 0.673 & 0.809 \\
\hline Inspirational Motivation & 15.513 & 314 & 0.000 & 0.543 & 0.701 \\
\hline Intellectual Excitement & 13.447 & 314 & 0.000 & 0.460 & 0.617 \\
\hline $\begin{array}{c}\text { Individual } \\
\text { Considerations }\end{array}$ & 11.578 & 314 & 0.000 & 0.428 & 0.603 \\
\hline $\begin{array}{l}\text { Transformational } \\
\text { Leadership }\end{array}$ & 17.181 & 314 & 0.000 & 0.535 & 0.673 \\
\hline Teachers' Empowerment & 18.434 & 314 & 0.000 & 0.582 & 0.721 \\
\hline
\end{tabular}

$\mathrm{t}$-tabulated $=2.01, \alpha \leq 0.05, \mathrm{df}=1$

Results above indicate that the counted ( $\mathrm{t}$ ) value equals 21.304 it is higher than the tabulated $(\mathrm{t})$, it is 2.01 . This means that practices of Transformational Leadership exists at a good level in the sample of study, and what certifies that is the level of significance that equals 0.000 ..it is less than level of significance test.. it is 0.05 . Thereupon we refuse the zero hypothesis that says; there is no acceptable level of transformational leadership practices at principals of schools and we accept the substitute hypothesis, that says: there exists acceptable level from practices of transformational leadership at principals of Public Secondary Schools at both regions of Muaqqar and Al-Jeeza in the Hashemite Kingdom of Jordan.

And in the same way in explaining and testing the hypothesis, results showed non-existence of subsidiary hypothesis belonging to the first main hypothesis and we accept the substitute hypothesis that word on, there exists acceptable level of practices of each of ideal influence, inspirational motivation, intellectual excitement and the individual considerations at principals of Public Secondary Schools at both Directorates of Muaqqar and Al-Jeeza in Shahab Zone in the Hashemite Kingdom of Jordan. This result had been deduced, because values of (t) for all elements of transformational leadership indicated, they are: 21.0304, 15.513, 13.447, 115.78 all are 
higher than the tabulated (t)...it is 2.01 . Also the level of significance for all these elements equals 0.000 and it is less than the level of test significance.. it is 0.05 .

\subsubsection{Test of the second main hypothesis:}

This hypothesis had been formed to test the level of empowering teachers at the Public Secondary Schools at both regions of Muaqqar and Al-Jeeza. The same test had been employed in testing the first main hypothesis.. it is the test with two limits. The existing results in table No. (6) concerning empowerment of teachers that the counted $(\mathrm{t})$ value equals 18.434 .. it is higher than the value of tabulated $(\mathrm{t})$.. it is 2.01 . Also the level of significance equals 0.000 . it is less than the level of test significance.. it is 0.05 . Therefore, we refuse the zero hypothesis and accept the substitute hypothesis that words: an accepted level exists from teachers' empowerment at the Public Secondary Schools at both regions of Muaqqar and Al-Jeeza in the Hashemite Kingdom of Jordan.

\subsubsection{Test of the third main hypothesis:}

This hypothesis is concerned with studying the effect of the transformational leadership practices in empowering employees in the sample of study. Linear Regression had been employed to testing the zero hypothesis. Results of analysis came as in table No. (7). Results had shown beginning with existence of strong correlative relationship between the independent variable (practices of transformational leadership) and the subordinate variable (teachers' empowerment) equals 0.827 and the value of Coefficient of Determination $\left(R^{2}\right)$ equals 0.683 , that is, practices of transformational leadership is responsible for $\% 68.3$ from empowering employees at the mentioned schools.. it is a great influence and what assures that is that the value of counted (f) equals .842675 . It is higher than the value of tabulated (f) amounting 4.05. That is too certified that level of significance equals 0.000 . It is less than the level of test significance.. it is 0.05 . Thereupon, we refuse the zero hypothesis and accept the substitute hypothesis that says: there exists an effect with statistical significance to practices of transformational leadership in empowering employees at the Public Secondary Schools at both regions of Muaqqar and Al-Jeeza in the Hashemite Kingdom of Jordan. The same test also showed that the subsidiary elements of the transformational leadership all of them showed the effect with statistical significance in empowering employees as illustrated in table 7.

Table 7. Test of effect hypothesis by employing linear regression

\begin{tabular}{|c|c|c|c|c|c|c|c|c|}
\hline $\begin{array}{c}\text { Subsidiary } \\
\text { Independent } \\
\text { variable }\end{array}$ & $\begin{array}{l}\text { Correlation } \\
\text { coefficient } R\end{array}$ & $\begin{array}{l}\text { Specification } \\
\text { coefficient } R 2\end{array}$ & $\begin{array}{l}\text { Counted } \\
\text { (f) value }\end{array}$ & $\begin{array}{l}\text { Freedom } \\
\text { degree df }\end{array}$ & $\begin{array}{c}\text { Level of } \\
\text { significance }\end{array}$ & $\begin{array}{c}\text { Linear } \\
\text { regression } \\
\beta\end{array}$ & $\begin{array}{c}(t) \\
\text { valve }\end{array}$ & $\begin{array}{l}\text { Level of } \\
\text { significance }\end{array}$ \\
\hline Ideal Influence & & & $\mathrm{R}=0.827$ & & & .135 & 2.707 & 0.007 \\
\hline $\begin{array}{l}\text { Inspirational } \\
\text { Motivation }\end{array}$ & & & $R 2=0.68$ & & & 0.225 & 4.121 & 0.000 \\
\hline $\begin{array}{l}\text { Intellectual } \\
\text { Excitement }\end{array}$ & & & $F=675.8$ & & & 0.164 & 2.864 & 0.004 \\
\hline $\begin{array}{c}\text { Individual } \\
\text { Considerations }\end{array}$ & & & $\begin{aligned} \mathrm{df} & =314 \\
\mathrm{Sig} & =0.000\end{aligned}$ & & & 0.418 & 8.132 & 0.000 \\
\hline
\end{tabular}

F-tabulated $=4.02$, t-tabulated $=2.01, \alpha<0.05, \mathrm{df}=1$

\section{Results Discussion}

After doing the hoped statistical analysis and testing hypothesis, the study had deduced the following results:

1. Rate of female teachers at the community of study surpasses the rate of males (females $\% 619$ and males \%38.1).

This is a positive indicator to the woman's role in the educational process and in the human development in the community. The majority of teachers are from bearers of Bachelor of Arts (\%88.3) and this is indicator to height of the academic level of teachers at that region, in addition to what preceded, results had shown that \%79.4 of teachers of both sexes are from youths below the age of forty.. this is another positive indicator too.

2. There exists an acceptable level of the transformational leadership practices at principals of the Public Secondary Schools at both regions of Muaqqar and Al-Jeeza in the Hashemite Kingdom of Jordan. The acceptable level at all practices: ideal influence, inspirational motivation, intellectual excitement, and the individual considerations at the indicated principals.

3. The study also showed existence of acceptable level from empowering teachers at those schools. 
4. Finally, the study had shown existence of effect with statistical significance of the transformational leadership practices on empowering employees at the Public Secondary Schools at both regions of Muaqqar and Al-Jeeza in the Hashemite Kingdom of Jordan.

\section{References}

Al-Jabri, Abdullah Mohammad (2018). Degree of Transformational Leadership dimensions at heads of Scientific Departments at the Faculty of Educational Sciences in King Saud University. Specialized Educational Journal, 7(3) March, 2018.

Al-Kharabsheh, Omar Mohammad \& Ayman Odeh al-Maani (2016). Effect of Applying the Transformational Leadership on Administrative Invation at Employees in Balqa Applied University.

Al-Rashidi, Ali Daban (2018). Transformational Leadership and Relationship with Organizational Invation at Public Universities' Deans at Riyadh City. The Arab Journal for Security Studies, 33(71), Riyadh 2018.

Al-Shammari, Fahd Mohammad (2017). Employing the Introduction of the Transformational Leadership in Developing Management of Intermediate Schools in the State of Kuwait Arab. Journal for Educational and Psychological Science, 18(3), 2017.

Al-Somail \& Mutwali (2018). Effect of Transformational Leadership on Empowering and Invation Administrative Employees Working at Higher Education Institutions in the Saudi Arab Kingdom: A Field Study on Administrative Employees in King Abdel Aziz University.

Aio, B, Bass. B \& Jung. D (1999). Transformational \& Transactional Leadership Using Multifactor Leadership Questionnaire. Journal of Occupational \& Organizational Psychology, (72).https://doi.org/10.1348/096317999166789

Aio, B.J (1994). The Natural Some Antecedence to Transformational Leadership International Journal of Public Administration, 17(9), 1559-1581.https://doi.org/10.1080/01900699408524956

Barbuto. J \& Burbach. M (2006). The emotional intelligence of transformational leaders: A field study of elected officials, The Journal of Social Psychology, 146(1), 51-64.https://doi.org/10.3200/SOCP.146.1.51-64

Bass, B.M. (1994). Improving Organizational effective through Transformational Leadership, London, Sage Publications.

Bass, B.M., Avilo, B.J. \& Goodheim, L. (1987). Biography and the assessment of transformational leadership at the world- class level, Journal of Management, 13 Spring.https://doi.org/10.1177/014920638701300102

Burns. J (2004). Transformational Leadership: A new Pursuit of Happiness, Grove Press. New York, USA.

Burns. J. (1978). Leadership, New York, Harple \& Raw.

Ghannam, Amira (2017). Effect of Transformational Leadership on Empowering Employees, A Field Study at Equipping Desert Rooms, Ein Media, Algeria.

Hause, R \& Aditya, R (1997). The Social Scientific Study of Leadership. Quo Vadis? Journal of Management, 23(3)https://doi.org/10.1177/014920639702300306

Ismael, Mohammad Ahmad (2015). What is the Concept of the Transformational Leadership? a published article on the Arab Forum for Human Resources.

Jacobs S. Tricia (2017). High School Teachers Perception of Empowerment ProQuest LLC, Parkway, USA.

Khaireddin. M. A (2015). The Impact of Big Five Personality Traits on Leadership Style International Journal of Business \& Management, 10(9), Canadian Center of Science \& Education.https://doi.org/10.5539/ijbm.v10n9p193

Nabil, Sarah (2015). What is the Concept of Transformational Leadership, a published article on the Arab Forum for Human Resources.

Tomey, A. M (2009). Guide to Nursing Management \& Leadership Canada Mosby Elsevier.

Woods. R (2003). Inspiration Leadership Model International Leadership Studies Conference.

\section{Copyrights}

Copyright for this article is retained by the author(s), with first publication rights granted to the journal.

This is an open-access article distributed under the terms and conditions of the Creative Commons Attribution license (http://creativecommons.org/licenses/by/4.0/). 